\title{
Bemutató céljára épített mechatronikai rendszer fejlesztése
}

\section{Development of a Mechatronic System for Demonstration Purpose}

\author{
Györkovács István, ${ }^{1}$ Forgó Zoltán ${ }^{2}$ \\ ${ }^{1}$ Sapientia EMTE, Marosvásárhelyi Kar, Gépészmérnöki Tanszék. Marosvásárhely, Románia, \\ gyorkovacs12@gmail.com \\ ${ }^{2}$ Sapientia EMTE, Marosvásárhelyi Kar, Gépészmérnöki Tanszék. Marosvásárhely, Románia, \\ zforgo@ms.sapientia.ro
}

\begin{abstract}
The aim of the paper is to present a modular system, with the help of which it is possible to reveal the structure and analysis of a mechatronic system, taking into account several disciplines that contribute to the structure of the system. The planned system will include devices from different disciplines, the operation and coordination of which will be observable. The designed system is a two-degree-of-freedom mechanism with a translational and a rotary joint. The movement of the joints are obtained by different types of energy converters (pneumatic, electric). The replacement of the different types of drives can be performed quickly and easily without drastically changing the system setup. The simulations are implemented using the MATLAB Simscape software package.
\end{abstract}

Keywords: mechatronic system, energy converters, joints, mechanism, simulation.

\section{Összefoglalás}

A dolgozat célja egy moduláris rendszer bemutatása, mely segítségével lehetőség nyílik egy mechatronikai rendszer felépítését és elemzését felfedni, figyelembe véve több tudományterületet, mely hozzájárul a rendszer felépítéséhez. A tervezett rendszerben különböző tudományterületekről érkező eszközök lesznek megtalálhatóak, amelyek működése és összehangolása lesz megfigyelhető és tanulmányozható. A tervezett rendszer egy két szabadságfokú mechanizmus, amely egy transzlációs és egy rotációs csuklóval rendelkezik. A csuklók a mozgásukat különböző típusú energiaátalakítókból nyerik (pneumatikus, villamos energia). A különböző hajtások cseréje egyszerűen és gyorsan végrehajtható, a rendszer alakjának és összetételének erőteljes megváltoztatása nélkül. A szimulálások a MATLAB Simscape szoftvecsomag felületén keresztül valósulnak meg.

Kulcsszavak: mechatronikai rendszer, energiaátalakítók, csuklók, mechanizmus, szimuláció.

\section{Bevezetés}

Napjainkban a mechatronikai rendszerek anynyira elterjedtek, hogy majdnem mindenhol megtalálhatók körülöttünk: találkozhatunk velük a munkahelyeken, de az otthonainkban is. Az ipar különböző területein is nélkülözhetetlen szerepet töltenek be [1]. Az elektronika, a gépészet és az intelligens számítógépes vezérlés egymást erősítő integrációja figyelhető meg ezekben a rendszerekben [2, 3].

Az indulásnál felmerült egy olyan kérdés, hogy hogyan lehetne egy olyan rendszert tervezni, amelyen bemutatható lesz, hogy mi is áll az a szó mögött, hogy mechatronika, hogy milyen tudományterületek alkotják. Tehát egy olyan rendszer szükséges, amelyben mind a gépészet, mind 
a villamosság és mind a vezérlés-programozás területéről érkező eszközök, alkatrészek helyet kapnak [1-3]. A legegyszerübben megvalósíthatónak ezen elképzelések mellett egy két szabadságfokú, soros robotkar, melynek egy transzlációs csuklója és egy rotációs csuklója lesz. Ezek a csuklók különböző energiaátalakítók, és mechanizmusok hajtják, így biztosítva minél több eszköz működésének, alkatrészeinek bemutathatóságát. A csuklók több meghajtó energia-átalakítóval/ mechanizmussal való felszerelhetősége egy új követelményt is behozott a tervezés kapcsán: ezek gyors és egyszerű cserélhetőségét. Tehát a csuklókat meghajtó eszközök gyorsan és egyszerűen leválaszthatóak és felszerelhetőek kell, hogy legyenek anélkül, hogy a berendezés fő részét szét kelljen szerelni.

\section{A berendezés tervezése}

A tervezett moduláris rendszer egy szemléltetőeszközként kell, hogy működjön, melyen jól láthatóak és tanulmányozhatóak a különböző alkatrészek, mechanizmusok, energiaátalakítók, amelyek a rendszert alkotják.

A tervezés első fázisában a tervezendő moduláris rendszer típusa, illetve maximális geometriai méretei lettek meghatározva. Ebből kiindulva egy rotációs és egy transzlációs csuklót tartalmaz, és ezáltal is minél többfajta hajtás bemutatására lesz alkalmas.

A berendezés bázisához az első kar egy transzlációs csuklóval kapcsolódik, majd ezt követi egy rotációs csukló. Ezek helyzete látható a 1. ábrán, amely a kinematikai vázlatot tartalmazza. Ezek alapján a bemutató berendezés testmodellje az Autodesk Inventor tervezőprogram segítségével készült el.

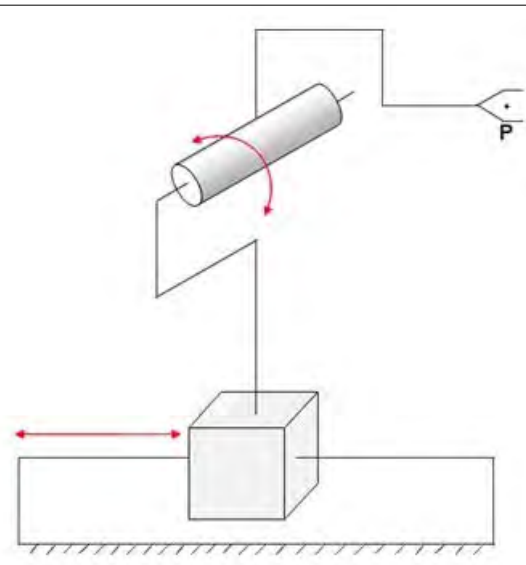

1. ábra. A berendezés kinematikai vázlata

\subsection{A transzlációs rész tervezése}

A tervezett berendezés transzlációs részének alapja egy lineáris golyós vezetősín, amely a 2. ábrán látható, és 8 darab M10-es süllyesztett fejü csavar segítségével van rögzítve az asztallaphoz (1).

A transzlációs mozgást a sínen lévő csúszka (2) valósítja meg. A sín (3) hossza 650 mm, így biztosítva, hogy minden típusú hajtás esetén megvalósuljon az 500 mm-es mozgási táv.

A 2. ábrán még látható egy állvány (4) a sín egyik végén, ennek az állványnak a feladata a különböző energiaátalakítóknak a rögzítése. A mechanizmus többi részének az alátámasztása érdekében a csúszkára egy állvány (5) került, amely alsó és felső lapjának mérete megegyezik a csúszka méreteivel.

A transzlációs rész mozgatása négytípusú energiaátalakítóval valósítható meg:

- pneumatikus hajtás;

- golyósorsos hajtás;

- fogasléces hajtás;

- forgókaros hajtás.

Hely hiányában, a felsorolt hajtástípusok közül csak a golyósorsos hajtás lesz bemutatva, illetve a szimuláció is ezzel a hajtástípussal készült el. A pneumatikus hajtás esetében a csúszka mozgását egy 500 mm-es lökethosszú, kétszeres működtetésű munkahenger biztosítja. A fogasléces hajtás esetében a léptetőmotor forgó mozgását egy fogaskerék-fogasléc páros alakítja át transzlációs mozgássá. A forgókaros hajtásnál a léptetőmotor forgó mozgásának átalakításáért egy hajtó és egy hajtott kar felel.

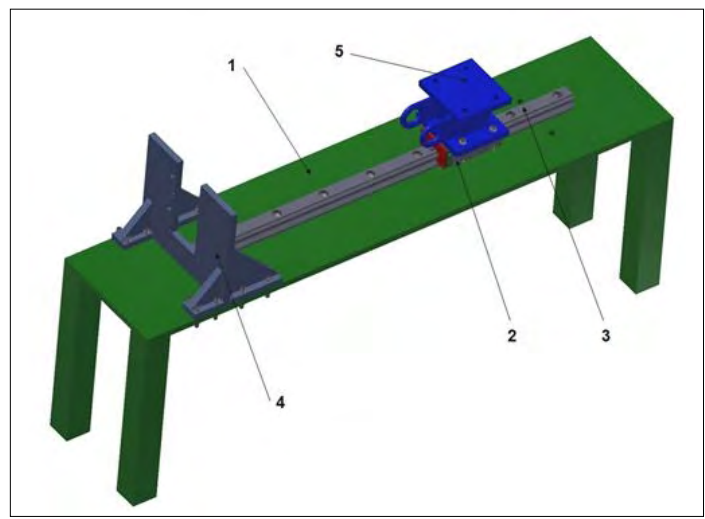

2. ábra. A transzlációs rész felépítése: 1-asztallap, 2-csúszka, 3-sín, 4-hajtásrögzítő állvány, 5- csúszkán lévő állvány. 


\section{A golyósorsós hajtás leírása:}

A második típusú hajtásnál (3. ábra) a villamos energiát alkalmazzuk egy léptetőmotor (1) segítségével. A motor forgómozgását egy golyósorsó-golyóanya páros alakítja át transzlációs mozgássá. A választott golyósorsó (2) egy 600 mm hosszú (melyből a menetes rész $513 \mathrm{~mm}$ ), $12 \mathrm{~mm}$ névleges átmérőjü, $2 \mathrm{~mm}$ golyóátmérőjü, C7-es precíziós osztályba tartozó, jobb menetes, hengerelt golyósorsó. A golyósanya (3) RSH-típusú, menetes felfogatási lehetőséggel.

A golyósorsó-golyóanya páros a 3.ábrán látható módon van beszerelve a rendszerbe. A golyósanya (3) egy M10-es csavarkötésen keresztül kapcsolódik a piros összekötő alkatrésszel (4), a csúszkán lévő állványhoz (9) pedig két, $20 \mathrm{~mm}$ hosszú, 25 mm átmérőjü acélszeggel (8) csatlakozik. A golyósorsó (2) a csúszkán található állvány (9) közepén halad át, ebből a célból az állványon található egy $28 \mathrm{~mm}$ átmérőjü furat. Az orsón (2) a menetes rész két vége csapágyazva van, a csapágybefogók (6) két-két M5-ös süllyesztett fejü csavarral vannak rögzítve az asztallaphoz (5). A csapágyak beszorítása egy-egy M5-ös csavarral történik, lineáris mozgásukat pedig a csapágybefogón (6) és a golyósorson (2) kialakított vállak akadályozzák. A léptetőmotor (1) tengelye egy Oldham-tengelykapcsolón (10) keresztül kapcsolódik a golyósorsóhoz. Az említett tengelykapcsoló megenged egy kis sugárirányú eltérést a motor tengelye és a golyósorsó között, és kisebb helyet foglal el, mint a más típusú tengelykapcsolók.

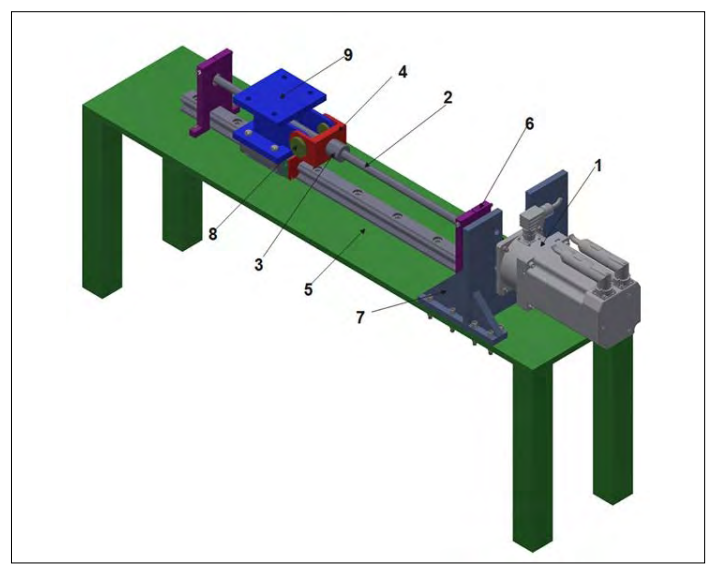

3. ábra. A golyósorsos hajtással felszerelt transzlációs rész modellje: 1- léptetőmotor, 2- golyósorsó, 3- golyósanya, 4- összekötő alkatrész, 5- asztallap, 6- csapágybefogó, 7- hajtásrögzítő állvány, 8- acélszeg, 9- a csúszkán lévő állvány.

\subsection{A rotációs rész tervezése}

$\mathrm{Az}$ általam tervezett berendezés rotációs része a 4. ábrán látható, két fő alkotóelemből áll: az alapból (5) és a karból (1).

A sárga alap (2) egy 210 mm hosszú, 140 mm széles és $10 \mathrm{~mm}$ vastag alumíniumlemezből és egy $100 \mathrm{~mm}$ hosszú, $30 \times 30 \mathrm{~mm}$-es alumíniumtömbből van kialakítva. A $30 \times 30$-as alumíniumtömb helye az alumíniumlemezen úgy van meghatározva, hogy amikor a talpat (5) és a kart (1) felszerelik a csúszkán lévő állványra (6), akkor a kar (1) függőleges helyzetében a csúszkán lévő állvány felületének közepén legyen. Amint a 4. ábrán is megfigyelhető, a talp (5) felülete nagyobb, mint a csúzkán lévő állvány (6) felülete, ennek az az oka, hogy a rotációs rész meghajtását segítő energia-átalakítókat lehessen rögzíteni. A kar (1) két $15 \mathrm{~mm}$ belsőátmérőjű golyóscsapágyon keresztül kapcsolódik a talphoz, itt alakul ki a rotációs csukló. A kar (1) egy 300 mm hosszú, $20 \times 30$ mm-es alumínium zártszelvényből készül.

A rotációs rész meghajtása háromtípusú energiaátalakítóval vagy mechanizmussal történik:

- munkahengerrel történő pneumatikus hajtás;

- léptetőmotoros hajtás;

- léptetőmotoros hajtás fogasszíjjal.

A rotációs hajtástípusok közül csak a léptetőmotoros hajtás lesz továbbá bemutatva, mivel a szimulálás során ez a hajtástípus volt felszerelve a berendezésre. A pneumatikus hajtás esetén a rotációs kar elfordulását egy 150 mm-es lökethosszú, kétszeres működtetésű munkahenger

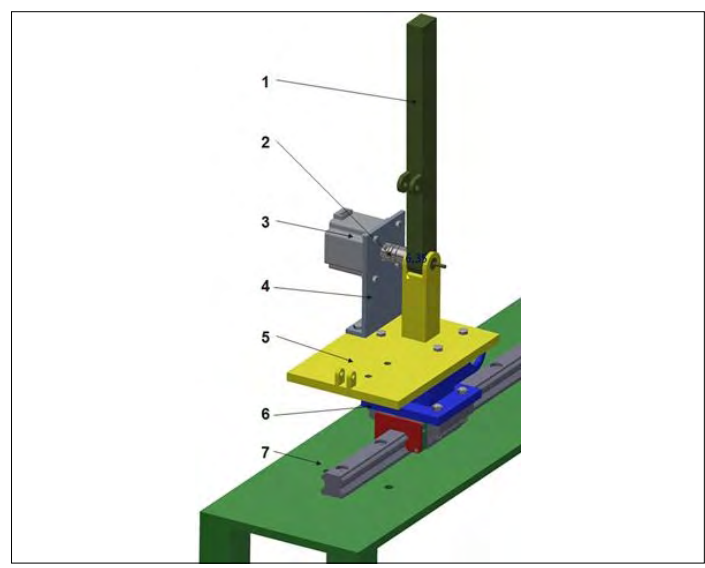

4. ábra. A berendezés rotációs része a léptetőmotoros meghajtással felszerelve: 1- kar, 2- tengelykapcsoló, 3- léptetömotor, 4- motortartó, 5-rotációscsukló-alap, 6- csúszkán lévő állvány, 7- asztallap. 
biztosítja. A fogasszíjhajtás esetén a léptetőmotor forgó mozgása egy fogasszíjáttételen keresztül adódik át a rotációs csuklónak.

\section{A léptetőmotoros hajtás leírása:}

Ennél a meghajtástípusnál (4. ábra) a motor (3) forgása egy tengelykapcsoló segítségével a rotációs csukló tengelyére kerül át, tehát a kar (1) forgási sebessége megegyezik a léptetőmotor (3) rotorjának forgási sebességével.

A motortartó állvány (4) két M8-as csavarral van felfogatva a rotációscsukló-alapra (5), úgy, hogy a léptetőmotor (3) rotorja és a rotációs csukló tengelye egytengelyü legyen. Az állvány (4) egy $5 \mathrm{~mm}$ vastag alumíniumlemezből készül. A léptetőmotor (3) tengelye és a rotációs csukló tengelye egy $6 \mathrm{~mm}$-es belső átmérőjű csőmembrános tengelykapcsoló (2) segítségével kapcsolódik, azért választottam ezt a típusú tengelykapcsolót, mert elnyeli a két tengely közötti szög-, párhuzamossági hibákat.

\section{A berendezés szimulációja}

A berendezés szimulálása a MATLAB Simulink felületén keresztül történt, így megteremthetőek azok a körülmények a berendezés számára, amelyekkel a valós környezetben találkozna a müködése során.

A szimuláció során a bemutatott mechanizmus karakterisztikus pontját (P) egy függőleges egyenes mentén mozgatjuk (5. ábra).

\subsection{A szimulációhoz szükséges számítások}

Ahhoz, hogy a karakterisztikus pont a 5. ábrán látható függőleges egyenesen haladjon végig, a berendezés mindkét csuklója mozgásba kell, hogy jöjjön, tehát a $q_{1}$ és a $q_{2}$ csuklóparaméterek állandó változásban lesznek. A változásukat pedig egyegy egyenlet fogja leírni, amelyek a mechanizmus inverz geometriai feladatának segítségével határozhatóak meg.

Az inverz geometriai feladat megoldásához, a Denavit-Hartenberg-konvenciót alkalmazva, az 1. táblázatban látható paraméterek lesznek használva a modellezés során.

$\mathrm{Az}$ (1), (2), (3), (4) képletekbe behelyettesítve a paramétereket, és a szorzásokat elvégezve, majd az egyenletekből a $q_{1}$ és $q_{2}$ csuklóváltozókat kifejezve, meghatározhatók ezek értékei (5) a karakterisztikus pont koordinátájának és a mechanizmus geometriájának függvényében. Behelyettesítve a rendszer méreteit $\left(l_{1}=209 \mathrm{~mm}, l_{2}=290 \mathrm{~mm}\right.$, $\mathrm{l}_{3}=0 \mathrm{~mm}$ ), a csuklóváltozók parametrikus egyenletei lettek kiszámítva (6), melyek alapját képezik
1. táblázat. A Denavit-Hartenberg-paraméterek táblázata

\begin{tabular}{|c|c|c|c|c|}
\hline $\mathbf{D H}$ & $\boldsymbol{a}_{\mathbf{i}-\mathbf{1}}$ & $\mathbf{a}_{\mathbf{i}-\mathbf{1}}$ & $\boldsymbol{\theta}_{\mathbf{i}}$ & $\mathbf{d}_{\mathbf{i}}$ \\
\hline 1 & $-\pi / 2$ & 0 & $-\pi / 2$ & $\mathrm{l}_{3}+\mathrm{q}_{1}$ \\
\hline 2 & $\pi / 2$ & 11 & $0+\mathrm{q}_{2}$ & 0 \\
\hline
\end{tabular}

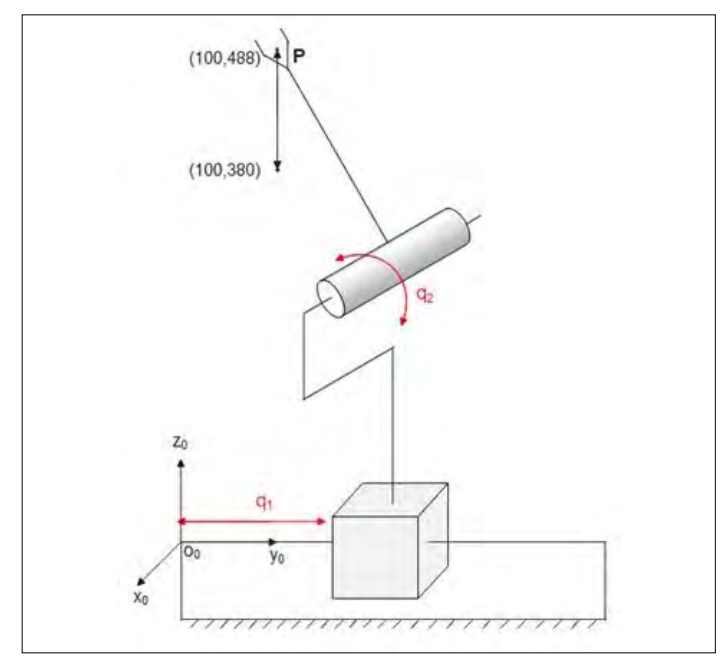

5. ábra. A berendezés vázlata a függőleges a karakterisztikus pont $(P)$ útvonalával, illetve a mechanizmus csuklóparamétereivel.

a Simulink modellben a rotációs és a transzlációs csuklók vezérlésének.

$$
\begin{aligned}
& {[\boldsymbol{T}]=\boldsymbol{T}_{R}\left(\boldsymbol{x}_{0},-\frac{\pi}{2}\right) \cdot \boldsymbol{T}_{T}\left(\boldsymbol{x}_{0}, 0\right) \cdot \boldsymbol{T}_{R}\left(\boldsymbol{z}_{1},-\frac{\pi}{2}\right) \cdot \boldsymbol{T}_{T}\left(\boldsymbol{z}_{1}, l_{3}+q_{1}\right)} \\
& {[\boldsymbol{T}]=\boldsymbol{T}_{R}\left(\boldsymbol{x}_{1}, \frac{\pi}{2}\right) \cdot \boldsymbol{T}_{T}\left(\boldsymbol{x}_{1}, l_{1}\right) \cdot \boldsymbol{T}_{R}\left(z_{2}, q_{2}\right) \cdot \boldsymbol{T}_{T}\left(\boldsymbol{z}_{2}, \mathrm{C}\right.} \\
& { }_{2}^{0}[\boldsymbol{T}]={ }_{1}^{0}[\boldsymbol{T}] \cdot{ }_{2}^{1}[\boldsymbol{T}] \\
& { }_{r P}^{0}={ }_{2}^{0}[\boldsymbol{T}] \cdot{ }^{2} r P \\
& q_{1}=\mathbf{y}_{P}-l_{3}-l_{2} \cdot \sin \left(\arccos \left(\frac{\mathbf{z}_{P}-l_{1}}{l_{2}}\right)\right) \\
& \left\{\begin{array}{c}
q_{1}=\boldsymbol{y}_{P}-290,488 \cdot \sin \left(\arccos \left(\frac{\boldsymbol{z}_{P}-209,512}{290,488}\right)\right. \\
\left.l_{2}\right)
\end{array}\right. \\
& q_{2}=\arccos \left(\frac{\boldsymbol{z}_{P}-209,512}{290,488}\right)
\end{aligned}
$$

\subsection{A szimuláció menete}

Az Autodesk Inventor szoftverben megtervezett háromdimenziós modellt a Simscape Multibody 
Link szoftvercsomag segítségével a MATLAB Simulink környezetbe lehet átültetni, ahol megfigyelhetővé és tanulmányozhatóvá válnak a különböző alkatrészek, alszerelések közti kapcsolatok, és lehetőség nyílik a berendezés működésének szimulálására is.

A szimulálás során a berendezés transzlációs csuklójának hajtásaként a golyósorsos megoldás van beszerelve, a rotációs csuklón pedig a léptetőmotoros hajtás kapott helyet. Ennek a rendszernek a Simscape MultiBody modellje látható az 6. ábrán. A szimulálás a rotációs (R-csukló) és a transzlációs (T-csukló) csuklóra az egyenletek szerinti mozgás bevitelével történt. Ebből adódóan a mozgás geometriai vezérlése a bemenetről van biztosítva, míg a mozgás megvalósításához szükséges dinamikus erőt és nyomatékot a rendszer számolja ki.

A középső, Mechanizmus nevű kék keretben található meg a rendszer alapja, és az ahhoz tartozó alkatrészek tömbjei (a tömbök azokat az alkatrészeket tartalmazzák, amelyek egymáshoz képest nem mozdulnak el):

- a tömb, amely magában foglalja az asztalt, a sínt, és a sín végén lévő állványt;

- a transzlációs csukló, amely a sínt és a csúszkát kapcsolja össze, ezt kell működtetni a $q_{1}$ paraméter (6) egyenletével;

- a csúszkaszerelés tömb, amely magában foglalja a csúszkát, a csúszkán lévő állványt és a rotációs rész alapját; -a rotációs csukló, amely a rotációs rész alapja és a rotációs kar közé van beépítve, ennek a hajtása történik a $\mathrm{q}_{2}$ paraméter (6) egyenletével;

- a végső kar tömbje.

A felső keretben található a rotációs rész hajtásának modellje, amely jelen esetben a léptetőmotoros hajtás, itt is megfigyelhetők a hajtást alkotó alkatrészek és azok kapcsolódása:

- a léptetőmotor-tartó tömb, amely tartalmazza a léptetőmotor, a léptetőmotor-állvány és a csőmembrános tengelykapcsoló modelljét;

- egy hengeres csukló rögzíti a rotációs csukló tengelyét és a léptetőmotor tengelyére szerelt csőmembrános tengelykapcsolót.

Az alsó keretben található a transzlációs rész hajtása, amely ebben az esetben a golyósorsos hajtás, itt is szintén megfigyelhetők a hajtás öszszetevői:

- a tömb, melyben a léptetőmotor és az Oldham-tengelykapcsoló kapott helyet;

- a csapágybefogó 1 és csapágybefogó 2 tömbökben a két csapágybefogó található, és a hozzájuk tartozó csapágyak;

- a golyósanya-szerelés tömbben a golyóanya és a köztes alkatrész kapott helyet, ezzel kapcsolódik a csúszkához;

- a golyósorsócsapágyakkal tömbben a golyósorsó található meg;

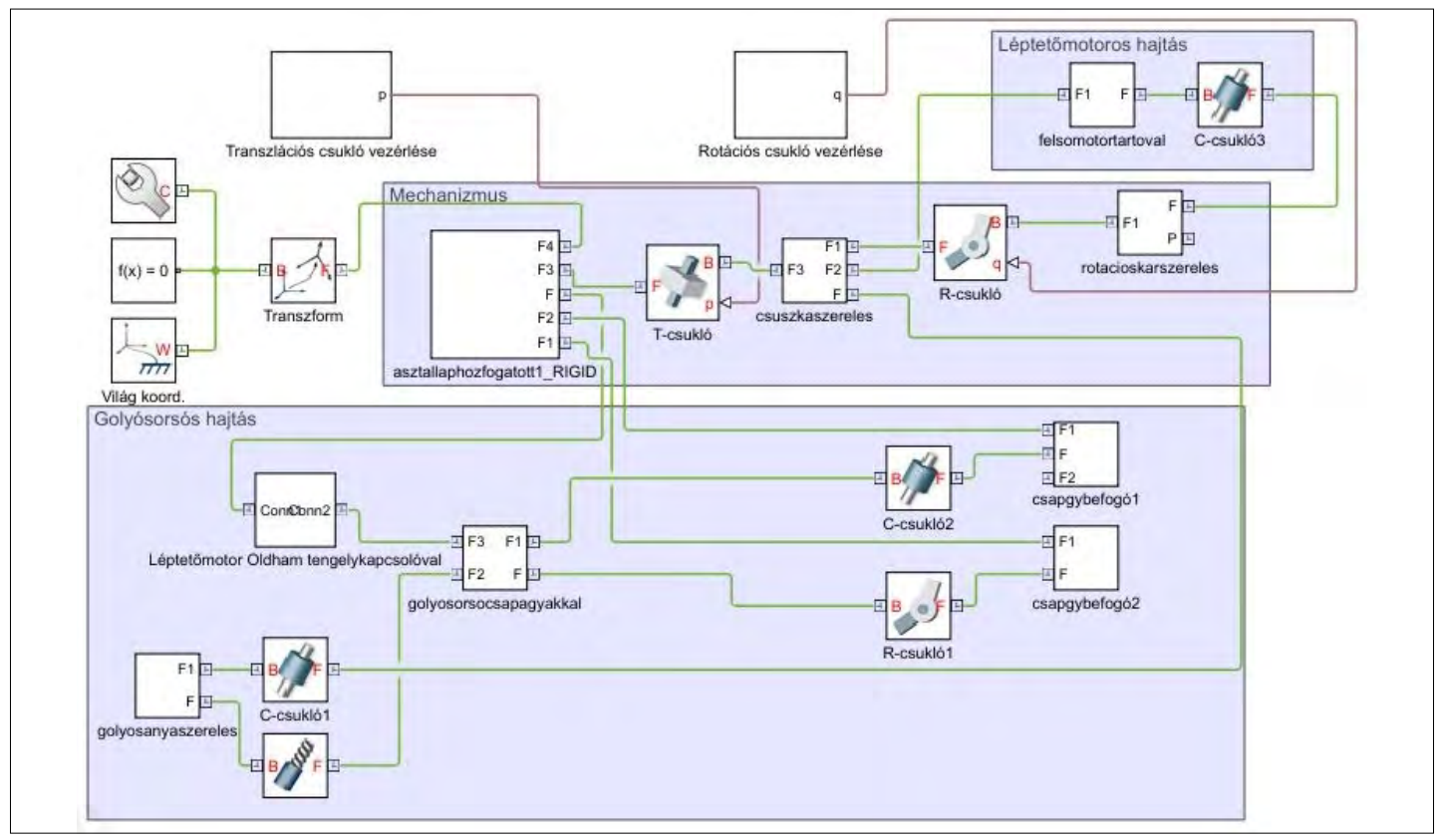

6. ábra. A szimulálás során használt Simscape MultiBody-modell 
- egy csavarcsuklón keresztül kapcsolódik össze a golyósorsó és a golyósanya.

Meg kell még említeni, hogy a szimuláció során csak a golyósorsos hajtást és a léptetőmotoros hajtás lett vizsgálva, viszont a Simscape-modell esetében is lehetőség van a transzlációs és a rotációs rész meghajtásainak típusának a cseréjére, mivel a modell is modulárisan készült.

Amint a 6.ábrán megfigyelhető, a rotációs csuklóba (R-csukló) a $q$ bemeneten keresztül van bekötve a mozgást megadó Rotációs csukló vezérlése nevű alrendszer. A transzlációs csuklóba (T-csukló) pedig a $p$ bemeneten keresztül van bekötve a mozgását meghatározó Transzlációs csukló vezérlése nevű alrendszer. Ebben a két alrendszerben vannak implementálva a (6) egyenletben meghatározott $q_{1}$ és $q_{2}$ csuklóváltozók egyenletei.

\subsection{A szimuláció kiértékelése}

A szimuláció végeztével lehetőségünk van a megjeleníteni különböző kinematikai és dinamikai paramétereket, melyek meghatározzák a rendszer működését. Például, ábrázolni lehet a karakterisztikus pont elmozdulását, sebességét, gyorsulását, a derékszögű viszonyítási rendszerhez képest, a szimuláció teljes idejére, vagy akár a csuklók elmozdulását, sebességét, gyorsulását, a rendszer működéséhez szükséges nyomatékokat/ erőket is lehetőség van meghatározni, majd számértékként vagy grafikusan megjeleníteni a szimuláció eredményeképpen.

\section{Következtetések}

Következtetésként összefoglalható, hogy sikerült megtervezni és szimulálni egy olyan moduláris rendszert, amelynek a segítségével lehetőség nyílik bemutatni és tanulmányozni egy mechatronikai rendszer felépítését, összetételét. A tervezés során előírt követelményeket sikerült teljesíteni: több energiaátalakítóval, mechanizmussal történő meghajtását a csuklóknak, a hajtások gyors és viszonylag egyszerű cserélhetőségét.

A berendezés tervezése és szimulálása során beigazolódtak a szakirodalmakban is leírt előnyeik és hátrányaik a különböző meghajtástípusoknak.

A pneumatikus hajtás esetében az előnyök: egyenes vonalú mozgások egyszerű megvalósítása, zavaró hatásokra kevésbé érzékeny, rugalmas (mechanikaisokk-elnyelő képesség). Hátrányai: viszonylag nagy energiaköltségek, egyenletes, állandó sebességű mozgások, a terheléstől függetlenül nem állíthatók elő.
A fogasléces hajtás előnyei a mechanikai egyszerűség, nagy terhelhetőség, míg hátránynak az esetleges holtjáték miatt pontatlan vezérlését és a gyengébb hatásfokot említhetjük.

A golyósorsos hajtás esetében a nagy pontosság, merevség, jó hatásfok, kicsi súrlódás a gördülő elemek között előnynek számít, míg a nagyobb beszerzési költség hátrányt jelenthet.

A forgókaros hajtás előnye az egyszerű felépítés, majd a nagy terhelés a motorra indításnál, illetve hátrány lehet, hogy a csúszka lineáris állandó sebességéhez a forgótengelyü motor megfelelő vezérlése szükséges.

Rotációs mozgás esetében a pneumatikus hajtás előnyei az egyszerű forgásirányváltás, az egyszerű vezérlőrendszer felépítése, károsodás nélkül viselik az esetleges túlterhelést, míg hátrányai a forgómozgás nehézkes megvalósítása, állandó sebességű mozgás terhelés függvényében nehezen előállítható, illetve nagy energiaköltségek.

A léptetőmotoros hajtás esetében a legjobb hatásfok, legkisebb energiaköltségek, pontos pozicionálhatóság kedvező megoldást jelent. Hátrányai között az alacsony fordulatszám, nem számítógépes környezetben bonyolultabb vezérlés, azonos teljesítmény mellett nagyobb tömeg jelenik meg, mely a rendszer dinamikáját befolyásolja kedvezőtlenül.

A fogasszíjhajtás előnyei: könnyen gyártható és szerelhető energiaátvitelt biztosít, jó hatásfokkal dolgozik (90-98\%), pontos szinkronhajtást tesz lehetővé. Fő hátrányának a gyengébb pozicionálhatóság említhető meg.

Mindezek által egy olyan mechanikai rendszert és modellezési, szimulálási eljárást valósítottunk meg, mely modularitásának segítségével a különböző megoldások kinematikai és dinamikai, leginkább oktatási célra történő összehasonlítását teszi lehetővé.

\section{Szakirodalmi hivatkozások}

[1] Forgó Z.: Bevezetés a Mechatronikába. Erdélyi Múzeum-Egyesület, Kolozsvár, 2009.

https://doi.org/10.36242/mtf-06

[2] Antal H., Aradi P., Czmerk A., Lakatos B., Chován T. és Varga T.: Mechatronikai berendezések tervezése. Kiadó BME MOGI, TÁMOP-4.1.2.A/1-11/1-2011-0042 projekt keretében készült, 2014.

[3] Bencsik A.: Mechatronika alapjai. Óbudai Egyetem, Bánki Donát Gépész és Biztonságtechnikai Mérnöki Kar, TÁMOP-4.1.2.A/1-11/1-2011-0054 projekt keretében készült, Budapest, 2014. 